This item is the archived peer-reviewed author-version of:

Democratic peace as a historical phenomenon

\title{
Reference:
}

Kustermans Jorg.- Democratic peace as a historical phenomenon

Journal of historical sociology - ISSN 0952-1909 - Hoboken, Wiley, 31:1(2018), p. E66-E77

Full text (Publisher's DOI): https://doi.org/10.1111/JOHS.12158

To cite this reference: https://hdl.handle.net/10067/1487710151162165141 


\section{Democratic Peace as a Historical Phenomenon}

Published in the Journal of Historical Sociology, DOI: 10.1111/johs.12158

Jorg Kustermans ${ }^{1}$

Democratic Peace: A Political Biography. By Piki Ish-Shalom. Ann Arbor, The University of Michigan Press, 2013. 280 pp., \$ 60.00 hardcover (ISBN-13: 978-0-472-11876-2).

The Rise of Democracy: Revolution, War and Transformations in International Politics since 1776. By Christopher Hobson. Edinburgh: Edinburgh University Press, 2015. 264 pp., $£ 75.00$ hardcover (ISBN-13: 978-0-748-69281-1).

War in Social Thought: Hobbes to the Present. By Hans Joas and Wolfgang Knöbl. Princeton, Princeton University Press, 2013. 336 pp., \$ 35.00 hardcover (ISBN-13: 978-0-691-15084-0).

Liberal Barbarism: The European Destruction of the Palace of the Emperor of China. By Erik Ringmar. Houndmills: Palgrave Macmillan, 2013. 268 pp., f 66.00 hardcover (ISBN-13: 978-1137-26890-7).

\section{Introduction ${ }^{2}$}

As with almost any subject in the study of international relations, research on the democratic peace finds itself stuck with history. The "fact of democratic peace" - at its most basic, the finding that two democracies have rarely fought a war with one another -

\footnotetext{
${ }^{1}$ Department of Political Science, University of Antwerp, Belgium.

${ }^{2}$ I would like to thank Brent Steele, Brecht Volders, Tom Sauer and Maarten Van Alstein for helpful feedback on an earlier version of the essay.
} 
emerges from a systematic inquiry into the history of international politics. Databases like the Correlates of War compile that history. That databases will often do injustice to the complexities of past events seems obvious and necessary: there can be no one-on-one reconstruction of the past. There is simply too much of it and with each passing day, nay minute, there is yet more of it. We must compile the past in order to get a handle on it. Any compilation of the past will present certain data and arrange them in a particular way. All historiography does this, and so does any (historical) database. The fact of democratic peace, for that reason, is and must be a historical finding, even when some theorists of the democratic peace claim trans-historical validity for it. One can make that claim only on the basis of historical research.

There is good and bad historical research. That is to say that there is more or less careful historiography (a fair consideration of available evidence, scholarly criticism of primary and secondary sources) and that there is more or less reflexive history (the explication of theoretical and political premises). Good historical research will also want to avoid fruitless anachronisms, which does not imply, however, that it must abjure a desire for general understanding. These standards of sound historical scholarship apply to democratic peace research too: (1) the construction of large scale historical databases demands great care, historical precision and, ultimately, judgment; (2) the qualitative inquiry into particular historical case studies, often on the basis of secondary sources, is particularly prone to theoretical biases (Elman 1997; Kratochwil 2006); (3) when scholars probe the validity of the theory of democratic peace in non-modern times (e.g., Russett 1993: ch. 3; 2009), the trap of anachronism is certainly lurking. 
The recent debate between Michael Poznansky (2015a,b) and Tarak Barkawi $(2015 a, b)$ in the (virtual) pages of International Studies Quarterly was in many ways a debate about the competent use of history in the social sciences. It discussed whether Cold War covert operations by the United States in Iran (1953) and Chile (1970-1973) do or do not falsify the democratic peace. Barkawi (2015a: 2) accused Poznansky of reproducing cold war ideology and, as a result, of misrepresenting the past. He takes him to charge for "[allying] his scientific reasoning with a long-dominant ideology and its interpretation of history." If the "historical record" (Barkawi 2015b) is properly scrutinized, with a politically sounder definition of democracy and a non-anachronistic definition of war, then U.S. covert operations will in fact be found to falsify the democratic peace, argues Barkawi. "Great contortions and distortions are necessary," he (ibid.) writes, "to reconcile such policies and events with the idea that democracies do not wage war on other democracies." In an earlier text, Barkawi (with Mark Laffey 1999) had noted more generally that democratic peace research anachronistically extends modern concepts of democracy into the past and applies obsolete concepts of war to the present. History, it becomes clear, is an important battleground for debates about the democratic peace. Historiography and arguments about good and bad history are among the contestants' more popular ammunition. Democratic peace, as mentioned before, is an historical finding.

More than an historical finding, however, the books that are being reviewed in this essay suggest that "democratic peace" is an historical phenomenon too. The very notion of a democratic peace arose in a particular time, in particular historical circumstances, and shaped up into tangible international practices in the way that it did because it arose in these circumstances. The concept and practice of democratic peace, that is, emerged from and further developed in a particular - but inevitably shifting - historical environment. To 
identify the "democratic peace" as a historical phenomenon invites a number of further questions.

1. Precisely when should we situate the emergence of a concept and practice of democratic peace and how should we typify the historical milieu in which it emerged?

2. Just how does "democratic peace" as a historical phenomenon relate to the democratic peace as a historical finding? Do both notions refer to the same behavior or activity? Or does the democratic peace as a historical phenomenon refer to something more or something different than the absence of war among democracies?

3. Does the idea that democratic peace is an historical phenomenon imply that it is a phenomenon of the past, that we are moving beyond the democratic peace? More generally, how does the particularity of the democratic peace as a historical phenomenon relate to the claim of trans-historical validity often ascribed to the historical finding?

The four books reviewed in this essay give different answers to these three questions or address different aspect of them. All agree that "democratic peace" is in one way or another an historical phenomenon and they also agree that the historical phenomenon does not coincide with the historical finding. The books, however, differ substantially (and more or less explicitly) about the meaning and implications of that claim. As such, taken together, they point toward an important avenue for further research (into the history of the concept and practice of democratic peace) and for further theorization (of the precise nature of the phenomenon that is democratic peace). 


\section{The Political Biography of Democratic Peace}

Democratic Peace: A Political Biography is the culmination of political theorist Piki IshShalom's more than decade-long work on the theory of democratic peace, some of which has been published in the more prominent journals in the field of International Relations. Ish-Shalom describes patterns of influence and interaction between social science, broader society and the world of foreign policy. He observes the operation of a hermeneutical mechanism whereby "theoretical constructions" become widely accepted as "public conventions" and sometimes wielded as "political convictions" for interested, political purposes. As theoretical concepts move from one stage to the next, they lose in accuracy but gain in persuasive power. It is as public conventions and even more so as political convictions that social science theories exert influence on concrete decision-making. IshShalom traces the operation of this mechanism for three "free world theories" - democratic peace, soft power, and capitalist peace - with the analysis of "democratic peace" being the central and best developed case study. He details the development of the notion of "democratic peace" from its scholarly announcement in Dean Babst's six-page article in the slightly obscure Wisconsin Sociologist, which heralded "elective governments as a force for peace," up to the Bush administration's justificatory references to the democratic peace in the run-up to the Iraq War of 2003.

The "misuse and abuse" $(111,28)^{3}$ of democratic peace research by hawkish American politicians has been noted and commented on before (Owen IV 2005). The observation that

\footnotetext{
${ }^{3}$ References with page numbers only refer to a page in the book that is primarily being reviewed in the section that includes that reference. In this first section after the introduction, they refer to Ish-Shalom's Democratic
} 
scientific findings risk morphing into rhetorical commonplaces as they enter the public domain is not that particular either. But Ish-Shalom's argument is much more specific and more complicated. Three aspects stand out.

First, Democratic Peace: A Political Biography contains an unexpected case study about the discursive uses of "democratic peace" in Israeli politics, where right wing politicians Benjamin Netanyahu and Nathan Sharanski conditioned peace negotiations with the Palestinians on the prior democratization of Palestine; unfair though, Ish-Shalom is careful to note, such expectation was. With multiple references to the theory of democratic peace, Netanyahu and Sharanski persuaded people to agree that negotiations with Palestine ought to be postponed until Palestine had become a democratic polity, or be avoided altogether (109-10). With the Israeli case, Ish-Shalom widens the empirical reach of existing case study research on the democratic peace and shows that the notion of a "democratic peace" had become, by the late 1990's, a rhetorical commonplace in international politics beyond the confines of American or Western-European foreign policy elites. At the same time, though, the Israeli case study makes clear that references to the democratic peace were somehow less heartfelt in the Israeli than in the American case. They resonated less with traditional self-understandings than they did in the United States and had been all but abandoned, as Ish-Shalom points out, by the end of the first decade of the new millennium (154).

Second, Ish-Shalom makes a sophisticated argument about the political nature of social science theories, including the democratic peace. Theories, he insists, are always "theoretical constructions," meaning that they are composed of "a configuration of political

Peace, in the second to Hobson's Rise of Democracy, in the third to Joas and Knöbl's War in Social Thought, and in the fourth to Ringmar's Liberal Barbarism. 
concepts endowed with meaning," and, as such, "offer more than mere explanations: they offer comprehensive readings of the phenomena under investigation, an entire world view of political phenomena" (18). With respect to theories of democratic peace, he explains how structural and normative explanations of the democratic peace, exemplified by Bueno de Mesquita et. al. (1999) and Maoz and Russett (1993), operate with divergent concepts of democracy and different concepts of peace. The normative explanation weds a participatory and deliberative concept of democracy to a so-called positive concept of peace, whereas the structural explanation of democratic peace weds an elitist concept of democracy to a socalled negative concept of peace (65-6). Structural explanations would express a conservative world view, whereas normative explanations would express a liberal, progressive world view. As a result, even when both stands of democratic peace theory can inspire a foreign policy that centers on the democratization of non-democratic countries, the liberal view will have a more demanding understanding of that process. From the conservative perspective, argues Ish-Shalom, democratization mainly requires institutional adaptations, whereas from the liberal perspective, democratization also demands farreaching societal and cultural changes.

The great merit of this account of social science theory as a form of political thought is that it makes the political-philosophical assessment (or typification) of theories of democratic peace immanent to the very theorization of democratic peace, both as a "theoretical construction" and as a "public convention" or "political conviction." The value hereof Ish-Shalom immediately demonstrates when he assesses neoconservative appropriations of the democratic peace in light of traditional (Burkean) conservative thought (112-113). His hope that the inclusion of normative theory into social science research will lower the chances of scientific research becoming "misused and abused" in the political 
realm does not persuade me, but the analytical and interpretive implications of the inclusion of normative theory into explanatory endeavors should certainly be explored.

This leads me to a third aspect of Ish-Shalom's thesis. He takes issue with a lot of constructivist scholarship for ignoring the role of "mundane politics, [to wit] politics with its own sets of reasons, interests, and maneuvers" (19) in the construction of social reality. It are political entrepreneurs who ultimately build reality through the [(unintended) effects of] their policies and decisions. They draw on ideas and participate in discourses, to be sure, but the part played by interested behavior in the whole process is irreducible and necessary. I think this is a correct observation although it leads, as a result of a certain overemphasis by Ish-Shalom, to a contestable interpretation of how the concept of democratic peace has historically affected international reality. Ish-Shalom often uses words like "misrepresent," "misuse and abuse," and "hijack" to denote political entrepreneurs' appropriation of democratic peace theory. These words - with their connotation of duplicity - unwittingly construct a dichotomy of good, disinterested scientists and bad, interested politicians; a dichotomy that sits ill with the earlier argument that social science theory, as theoretical construction, is a form of political thought. They also suggest that "democratic peace" became a public convention and political conviction only once it had been elaborated, from the mid 1960's on, as a social scientific "theoretical construction." The public convention of the late 1990's and 2000's distorts the theoretical construction of the 1980's and early 1990 's. But there is an argument that the public convention of the 1990's and 2000's is simply a re-articulation of an earlier public convention, into which the theoretical construction of the 1980's and 1990's was integrated in order to add to the public convention's rhetorical capital, to its persuasive power. This possibility does not contradict Ish-Shalom's claim about the necessary role of interested action in the construction of socio- 
political reality, but it does qualify the connotation of duplicity that Ish-Shalom imbues it with (through his choice of words and choice of "negative" case studies). Extending the history of "democratic peace" further back in time is more than an academic endeavor. It clarifies the form and meaning of its current and possibly future political significance. Words like "hijacking" or "misusing and abusing," I would argue, fail to grasp that process in an adequate way.

\section{The International Rise of Democracy}

Christopher Hobson wrote his The Rise of Democracy: Revolution, War, and Transformations in International Politics since 1776 in direct response to social scientific research on the democratic peace (18-44). The problem of most research on the democratic peace is not that it is wrong, he argues, but that its representation of social and political reality is somehow inadequate, that it does not correspond to the meaning of that field of social action that it is portraying. "[The] empirical correlation of a dyadic democratic peace has been widely accepted, even by critics," he writes (20). And also: "Despite the array of problems and challenges that democracies now face, none directly undermines the core dyadic claim" (23). But, believes Hobson, a singular focus on that finding threatens to render democratic peace research irrelevant. Constant attempts to "prove and disprove" (Barkawi 2015b) the absence of war among democracies has led "mainstream research [to miss] important dimensions of this phenomenon" (26; italics added). He cites the relative silence of democratic peace scholarship with respect to the American and British military engagement in Iraq, 2003, as an indication of the lack of attunement of this research program to real world processes. Historical research on the inter-relationships of the 
concepts of democracy, war, and peace - and into the events and practices that embodied (the contestation of) these concepts - should give us a more rounded understanding of the phenomenon. "The way 'democracy' has changed over time, and how it has been related to ideas such as 'war' and 'peace', has in turn shaped what 'democratic peace' means" (26; italics added).

Hobson's conceptual history is, by and large, successful in recounting the vagaries of the concept of democracy in the history of international politics and how that international history intertwines with domestic political histories of revolution (American, French, Russian), restoration, and transformation (rise of egalitarianism, but also Nazism and Fascism). Precisely what "meaning of democratic peace" emerges from those histories, however, this Hobson fails to specify with sufficient clarity, although "an image of its essence, its inclinations, its personality, its passions" $(120)^{4}$ can be gleaned from his account.

The Rise of Democracy establishes beyond doubt that "democratic peace" had become a public convention some time before the end of the Cold War. Consider two quotes from the late $18^{\text {th }}$ and early $20^{\text {th }}$ century respectively, both articulated by what Ish-Shalom would call political entrepreneurs, not by theoreticians.

"All unjust aggression is contrary to natural law; a nation has no more right to attack another nation than an individual has to attack another individual. A nation cannot therefore give a king the right to aggression that it does not have itself; the principle should above all be sacred for free nations. Were all nations free as we wish to be,

\footnotetext{
${ }^{4}$ Hobson is quoting Alexis de Tocqueville, who is describing what he ultimately wanted to understand about democracy: "its essence, its inclinations, its personality, its passions."
} 
there would be no more war." [A French deputy from Poitou, c. 1790] (86; emphasis added)

"A steadfast concert for peace can never be maintained except by a partnership of democratic nations. No autocratic government could be trusted to keep faith within it or observe its covenants. It must be a league of honor, a partnership of opinion [...]" [Woodrow Wilson, 1917] (145; emphasis added)

An important purpose of Hobson's account is to show the effort that went into establishing the commonplace of a democratic peace: how democracy had traditionally been associated with a lack of restraint, with mob rule and caprice; how "democracy" had traditionally been depicted as "a behavioral and ontological threat" to international peace and order, and how champions of democracy had to put great effort into signaling restraint and felt compelled, and often inclined, to domesticate the meaning of democracy, both at home and in terms of budding democracies' diplomatic ambitions $(55,129)$. Most often this is taken to mean, and so does Hobson take it, that "liberal concerns" were favored over "democratic ambitions." 5 But as the references to notions of "sacredness" and "honor" in the two quotes above suggest, and as Hans Joas and Wolfgang Knöbl's intellectual history (to be reviewed next) makes abundantly clear, there were always other dimensions to the international domestication of democracy. The concept of democratic peace was not only domesticated within a liberal project compatible "with the interests of the ruling classes" (139), but also sought to retain an association with traditional republican notions of honor and virtue (and thus keep "the few" and "the many" integrated through such notions as representation and

\footnotetext{
${ }^{5}$ Throughout the book Hobson makes a useful distinction between democracy as a form of state and democracy as a form of government. Democracy as a form of state would always be less threatening to traditional, elite-centered international society than democracy as a form of government.
} 
- more or less natural, or meritocratic - leadership). This observation adds further depth to Ish-Shalom's interpretation of the "institutional explanation" of the democratic peace as a conservative theory.

Hobson also makes clear that a public convention (and even a political conviction) does not have to reflect a mood of self-assurance. This is slightly paradoxical. In terms of style of delivery, this much we can agree with Ish-Shalom, public conventions and political convictions will be voiced with great confidence (and thus clash with the scientific habitus), but the substance of public conventions can well betray or express an appreciation of fragility. Hobson ends his book with a plea for more humility among advocates of democratic peace (204-220); a call that makes sense in light of the democratic triumphalism that marked the end of the Cold War and its alleged failure with the wars in Afghanistan and Iraq. But what Hobson's historical narrative shows, is that such triumphalism has historically been the exception rather than the rule. For the greater part of its history, the "democratic peace" has been a practice marked by restraint. The concept of "democratic peace," that is, historically only rarely prefigured a cosmopolitan or imperial project but more often took a defensive posture. As "democracy" established itself as a "basic concept" in world politics, and as it began to inform the institutions of international society, it nonetheless typically "[preserved] the anarchical nature of international politics" (151). The French revolutionary wars and Post-Cold War interventions have been - only partially, I would argue -exceptions to that rule.

I write "partially" for different reasons in each case. With respect to Post-Cold War interventions, I would argue that these interventions were primarily associated with a more general liberal project than with the more particular notion of democratic peace (with its 
lingering republican elements). It is instructive that the literature on these interventions does not go by the heading of democratic, but of liberal peace (e.g., Richmond 2006; Selby 2013). With respect to the French Revolutionary Wars, for its part, it appears from Hobson's account that the radicalization of the French Revolution and revolutionary's France's initiation of a sequence of European wars, maybe followed less from an ideological, democratic impulse than that it happened in (desperate) reaction to intra-revolutionary contention and reactionary, external interventions into French affairs such as the Declaration of Pillnitz of 1791 and the Brunswick Manifesto of 1792. France lashed out in a preemptive strike. It defended itself, although, to be sure, defense soon morphed into a years-long offensive campaign (cf. Tarrow 2015, 31-50).

\section{Democratic Peace in the History of Social Thought}

Christopher Hobson traces the meaning of "democratic peace" through a conceptual history of democracy in international politics. He has tracked a curious development from democracy being considered "behaviorally and ontologically threatening" by a traditionally aristocratic international society (102), to the "community of democracies" defining autocratic regimes as "behaviorally and ontologically threatening" to international order (147). There can be no peace, it appears, without an enemy. Hans Joas' and Wolfgang Knöbl's War in Social Thought: Hobbes to the Present adds considerably to our understanding of this somewhat paradoxical logic of (democratic) peace and how it fits within a wider set of irenic (and bellicose) practices. The authors foreground the problem of understanding (war and) peace and thus cut into the concept of democratic peace from the opposite end. 
War in Social Thought is not wholly or even primarily devoted to a discussion of the notion or theory of democratic peace, although it does identify democratic peace research as one of three central and important strands in present-day scholarly debates on war and peace; the other being current debates on "empire" and on "state failure and new wars." Rather the book presents a history of discourses on war and peace in Western social thought - an originally broad category that narrows down to sociological theory and social science research as their narrative develops - within which present research on the democratic peace assumes its significance by comparison to earlier theories of war and peace. Joas and Knöbl are skeptical about the democratic peace as a historical finding - primarily about its theorization, which they find lacking in historical awareness (221-222), but also about the very finding, which they think dissolves if the shifting meaning of democracy and the changing form of war are taken into account; a change in form which results at least partly, argue Joas and Knöbl, from politicians' desire to escape democratic scrutiny (229; cf. Barkawi 2015a,b).

Regarding the institutional or structural explanation of the democratic peace, they point out that this explanation holds assumptions about popular preferences for peace that are simply not tenable from a historical perspective. People - including citizens of democracies - have not generally opposed wars. They also suggest that wars have been fought between city-state republics although they shared, or so Joas and Knöbl argue, many of the institutional features that the structural explanation associates with democratic peace-proneness. As a result, the normative explanation must carry the weight of explaining the democratic peace, thus severely restricting the theory's historical scope of application (as well as its exportability and use in foreign policy). The democratic peace becomes a Western, post-Second World War phenomenon, about which Joas and Knöbl observe that 
this period of peace was causally overdetermined and which therefore tells us little about the future of peace, even in a fully liberal-democratic world (227).

Most of these arguments will be well-known to any observer of the debate on democratic peace. The authors' summary of it contains a dubious interpretation of Immanuel Kant's argument about republicanism and peace - which depicts Kant as having expressed the dyadic and cultural argument (222) - but is nevertheless a perceptive outline of the debates and has the merit of underscoring some of the historical inadequacies of democratic peace research as well as emphasizing the futility of mono-causal approaches to social explanation (217). However, their real contribution to our understanding of concepts of war and peace, and thus also potentially to our understanding of the notion of democratic peace, lies in the very premise that informs their book, namely that fundamental conceptions of man and human behavior, of social order, and of social change will underlie any theory of war and peace. This is true for traditional social thought, for modern academic theories, as well as for ordinary people's operational theories (Ish-Shalom's public conventions). ${ }^{6}$ Their account can be read in two ways. One the one hand, one can take them to argue that some theories of action, order and change fare better than others in grasping the preconditions and (limited) possibilities of peace. In this respect, they observe that modern social theory - which Joas and Knöbl associate with a rational theory of action, individualist theory of society, and a progressive theory of history - typically suppresses the problem of war. It cannot appreciate the historical endurance of war, nor its societal and personal significance or attractions. It is this underlying argument that gives extra meaning

\footnotetext{
"I would also mention that, by making "action" a concept that is immanent to theories of war and peace, Joas and Knöbl open space for a less negative account of "interested action" than the connotation of duplicity that Ish-Shalom imbues it with. For an introduction to the complexities of the notion of self-interest, cf. Barbalet (2012)
} 
to their criticism of modern democratic peace research. On the other hand, one can also take Joas and Knöbl to argue that particular concepts of personhood, society, and history constitute and permeate our concepts of war and peace, and consequently also our practices of war and peace, including of "democratic peace." Here the question becomes how social and political theories "imagine" war and peace and how they prefigure different practices of war and peace.

Compare Thomas Hobbes and Jean-Jacques Rousseau. For Hobbes, in tune with his rationalist and individualist anthropology, peace consisted in a situation of "mutual indifference" (17; with reference to Tuck 2002, 65). This is what marks out Hobbes as a liberal thinker. We find a reflection of this liberal concept of peace in the "normative explanation" of democratic peace which invokes the norm of live-and-let-live (Maoz and Russett 1993: 625). Very different, however, was Jean-Jacques Rousseau's concept of peace. Rousseau was an "anti-utilitarian" (49) and romantic thinker and one of the first to articulate a concept of democratic, or republican peace. "[...] Rousseau can envisage a more or less peaceful state of affairs only in the form of the coexistence of small autarkic republics" (49). But the environment will never be completely secure, so that in order to maintain this condition of autarkic, democratic peace, defensive militia have to be trained, and be "trained primarily for speed and lightness, to break formation, disperse, and regroup without strain or confusion; to excel in what is known as guerilla warfare, all the maneuvers appropriate to light troops, the art of sweeping over a country like a torrent, to strike everywhere without ever being struck" (48). Sporadic bouts of violence, for defensive purposes, are an inevitably dimension of every republic's policy for peace, thought Rousseau. He harbored no cosmopolitan dreams. He did not like war but thought it inevitable and ultimately productive of republican peace. 
In the middle of the twentieth century, Roger Caillois of the Collège de Sociologie, a group of French sociologists working within the Durkheimian tradition, elaborated a similar argument, but he emphasized more explicitly that the use of force was not only instrumentally functional in securing peace (as in a traditional notion of self-defense). He likened war to a primitive festival - a temporary period of exaltation - because both offer an intimation of "the sacred," a "restoration of true personal sovereignty," an experience which would animate, and keep meaningful, the subsequent period of peace (157-159). True peace, this kind of argument suggests, will always demand more than "mutual indifference." It must be more-than-profane. Hobson's book made clear that the concept of democratic peace would often establish, or retain, a certain association with the idea of sacredness and honor. Short eruptions of violence are crucial to the maintenance of peace, the argument further holds, much like exalting festivals were necessary to the maintenance of primitive societies. We should not expect "democratic peace" to escape this kind of dynamic. Erik Ringmar's book, to which I now turn, explores this possibility in great detail.

\section{An Account of a Particularly Violent Episode}

Based on meticulous primary-source-based empirical research, Liberal Barbarism: The European Destruction of the Palace of the Emperor of China tells the story of joint FrenchBritish military operation in the aftermath of the Second Opium War, the North China Campaign of 1860. At the end of that campaign, the British and French troops ran into Yuanmingyuan, an imperial palace and garden complex to the North of Beijing, which they destroyed. The French looted the place during two days and nights of frenzy and carnivalesque celebration. The British then burned it down and laid it to ruins with great 
systematicity. In terms of military strategy, these efforts were superfluous. Unlike during earlier engagements, the European allies had overwhelmed the Chinese militarily. They had won this war. In terms of morality, the behavior largely clashed with European selfunderstandings and with liberal principles of international morality as they were being codified in international law. Erik Ringmar's purpose is to account for this moment of transgression.

He explains that we should think of the destruction of Yuanmingyuan as an "awesome performance," "an action that is staged and carried out before an audience." A performance re-presents reality. "The purpose of the performance is to show this representation to the audience; the performance seeks to demonstrate, explain, or teach something, to convey sensations, emotions, and experiences" (27). The argument applies less to the French, whose looting, Ringmar observes, did not differ from the usual practice of colonial warfare. The rules of civilized behavior should not hamper European engagements with savages and barbarians, it was believed, because they could not be trusted to reciprocate. The French were not communicating much with their barbaric behavior. But the British were. Their actions were deliberately addressed to an audience. They addressed a domestic audience, which expected a firm response to the kidnapping of the members of a scouting expedition by the Chinese (an expedition, which had included the famous newspaper correspondent Thomas Bowlby as one of its members). But Lord Elgin, who headed the British mission, also had a Chinese audience in mind, in particular the Xianfeng emperor and other members of the resistant Chinese elites. To them Elgin wanted to signal that further resistance was futile: the liberal, international society of sovereign and equal states would definitively supplant traditional sino-centrism. The Opium Wars had been an attempt to force a liberal economic and political international order on the Chinese. And 
even though the European had won those wars, they still felt that they were losing the peace because the Chinese were forever backtracking on their promises. Only an "awesome performance" (21 ff, 135-149) would get these prideful Chinese finally onboard. Only a barbarian act of terror would wake up the Chinese emperor from his fantastical slumber. The performance duly impressed its audience. In its aftermath, the Chinese began reforming diplomatic education and became conversant with modern treatises on international law.

Liberal Barbarism reminded me of Tzvetan Todorov's The Conquest of America (1984), both in subject and in style. Ringmar does not call it that way, but his is an "exemplary history," which Todorov has defined as

A story that [is] as true as possible, but in telling which [the author] shall try never to lose sight of [...] its tropological or ethical meaning. [R]ather as in a novel, summaries or generalized perspectives will alternate with scenes or analyses of detail filled with quotations, and with pauses in which the author comments on what has just occurred, and of course with frequent ellipses or omissions. (Ibid. 4)

Exemplary history is ostensibly about the past but really seeks to elucidate a, typically moral, conundrum in the present (6). With Todorov it is the "question of the other." With Ringmar it is "liberal barbarism," the paradox that liberal people can - temporally - behave in the most barbaric way for liberal reasons, or at least for liberalism's sake.

A good part of Ringmar's analysis consists in typifying the paradox, of which the destruction of the Chinese emperor's palace was only a violent example. He elaborates one metaphor in particular to this end: the figure of the garden. Yuanmingyuan was a garden complex. Luscious Chinese garden design was something of a trend in nineteenth century Europe. Liberals needed their garden, for moments of repose from the frenzy of circulation 
and also for its curves and dead-ends, in a world that has become overly rationalized.

Liberals simultaneously abandon the garden and turn (paradisiacal) gardens into yards so that no land lays to waste. No land should lay to waste, liberals believed, so that in their encounter with primitive economies, the decision to colonize what appeared to be wasteland was easily justified. Liberals are certainly capable of feeling shame, much as Adam and Eve were, when they have given in again to their desire to know all and taste everything - to control everything - and understand the transgressions which it provoked and the destruction to which it has lead. But then shame is an unproductive emotion, the liberal persuades himself, and he repeats to himself that his actions - barbaric though they were must have added a fair amount to "the greatest happiness of the greatest number." To destroy the emperor's palace and garden complex sounds awful, certainly, until, that is, one takes into account its longer-term historical effects: freer trade for all, a nascent civil society for the Chinese, and, in due time, a thousand vegetables growing in millions and millions of tidy middle class garden lots.

If explicating the paradox of "liberal barbarism" is Ringmar's main purpose, his account does speak explicitly to any endeavor to historicize the democratic peace. First, he explains how a free press - a key institution of democratic polities - conjoined with rapidly rising literacy rates and the invention of "the nation" [which "added an interior life to the state" (24)], could render nineteenth century leaders more bellicose than they might have wanted to be. They felt compelled to appeal to public opinion, which savored scandals and sensations and cheered for any expression of colonial dauntlessness. One reason why the French only looted Yuanmingyuan and the British proceeded to utterly destroy it, was that in France there was not much of a free press, and thus little popular pressure on the French leaders of the mission, while in Britain the institution was much more developed and 
breathed into the British leaders' necks (121-133). This is a direct challenge to the institutional explanation of the democratic peace, as Joas and Knöbl had mentioned too. Second, Ringmar throws historical light on a common argument in modern democratic peace research, which holds that democracies cannot export their domestic liberal practices to their diplomacy with non-democracies, because with them (and because of them) they remain stuck in the traditional logic of anarchy. At the end of his book, Ringmar explains how civilized Europeans had developed a similar argument in defense of their roguish behavior in the colonies and places like China.

[They would] point to the imperatives of all wars fought in non-European settings. There was a difference between who the Europeans were at a [sic] home, they explained, and who their presence on the Chinese stage had turned them into. In Europe, they were their real selves - civilized, humanitarian peaceful - and the colonial wars were for that reason undertaken as if in disguise. "Barbarian" was only a role that they temporarily had been forced to assume. (164; italics added)

Democratic peace theory clearly participates in this same, "liberal" argumentative tradition. Ish-Shalom's observation that social science theories are theoretical constructions and, as such, a form of political thought proves correct again. Nevertheless, as I will argue in the conclusion, partly on the authority of Hobson's and Joas and Knöbl's analyses, but also in light of Ringmar's methodological example, we should not conclude too readily that, as a historical phenomenon, democratic peace falls squarely within this liberal tradition. We should at least entertain alternative interpretations.

\section{Conclusion}


It is a great merit of Piki Ish-Shalom's book that he has shown that "democratic peace" does not only exist in academic theories about the world, or emerge from scholarly observations of the world, but that it is a theory in that world too and that it intervenes into that world. Although he does not use the expression, with Ish-Shalom "democratic peace" becomes an historical phenomenon, a phenomenon situated in historical time and having an effect on a range of international developments. I have expressed reservations about Piki Ish-Shalom's elaboration of this key insight and have used the books by Christopher Hobson, Hans Joas and Wolfgang Knöbl, and Erik Ringmar to clarify the reasons for these reservations.

Returning to the three questions that I mentioned in the introduction to this essay will allow me to pointedly state our differences.

But I want to stress that the other books have their shortcomings too. Hobson is maybe overly focused on the very concept of democracy and could have done more to contextualize the conceptual developments that he traces within their (changing) cultural as opposed to exclusively political - environment. Hobson hints at that necessity but does not explore it much. One interesting question would be how the (international) history of democracy intersected with the - forever incomplete and reversible - process of secularization. Joas and Knöbl, for their part, cover too many authors and frameworks in too few pages. Their account becomes exhausting after a while and loses its interpretive coherency when it abandons its original focus on the significance of fundamental conceptions of action, order, and change for our understanding of war and peace. The book becomes, in the end, too much of a summary. It becomes a textbook rather than develop an original thesis. Ringmar, for his part, suffers from the opposite problem. His use of secondary sources is relatively sparse and he does not take rival scholarly interpretations into account 
much. ${ }^{7}$ His methodological practice is praiseworthy, his theoretical framework pleasantly pointed, his cultural interpretations richly textured and remarkably perceptive, but - and as a result of his being an exemplary history - too singular in that it risks identifying the nineteenth century with liberal processes, projects, and paradoxes. Ringmar does not ultimately make that identification (5), but, given the alluring quality of his account, it is worth emphasizing that alternative cultural histories of Western societies - their foreign policies and their violent moments included - can be written; with implications for how we interpret the meaning of democratic peace. This immediately brings us to our first question from the introduction.

1. Precisely when should we situate the emergence of a concept and practice of democratic peace and how should we typify the historical milieu in which it emerged?

Piki Ish-Shalom situates the development of the public convention of democratic peace in Western foreign policy circles at the end of the twentieth century. The theoretical construction "democratic peace" he dates back to the late 1960's and early 1970's. Democratic peace, for him, is a Cold War and Post-Cold War phenomenon. Hobson and Joas \& Knöbl show, however, that "democratic peace" existed as a public convention before that time. Hobson has a first quote from the late eighteenth century when a deputy to the Assembly expressed his belief that maintaining peace was a sacred purpose of free nations. Joas \& Knöbl find the articulation of a concept of democratic peace in the writing of both the Scottish Enlightenment, of Immanuel Kant, and of Jean-Jacques Rousseau. Very important, in this context, is to remark that neither of these thinkers can straightforwardly be branded a

\footnotetext{
${ }^{7}$ His rendition of the Chinese tributary system, for instance, could have benefited from a more direct engagement with alternative accounts of the sino-centric system (24-25; cf. Hevia 1995).
} 
liberal thinker. They clung to ancient concept of virtue and duty, which colored their imagination of democratic peace. Thomas Hippler $(2015,187)$ has traced a more explicitly liberal conception of democratic peace in the (discursive and performative) proceedings of the 1867 Peace Congress of Geneva, but also here faith was not so much put in a bland assumption of rationality than in a moralized notion of reasonableness (cf. Williams 2001).

2. Just how does "democratic peace" as a historical phenomenon relate to the democratic peace as a historical finding? Do both notions refer to the same behavior or activity?

None of the above analyses contradicts the empirical observation that two democracies have rarely fought one another in a war that resulted in more than 1.000 battle-related deaths. Ish-Shalom accepts the finding and praises democratic peace research for its methodological sophistication. Hobson accepts the finding as well but judges research on the finding to be driven by narrow concerns and increasingly irrelevant in light of important developments in the field of international security and in light of democracies' more general security behavior. Joas and Knöbl and Ringmar are more critical still. The former explain that the democratic peace would dissolve if a historically variable concept of war were to be accepted. Covert action was a form that war took as democratic leaders felt constrained to engage in overt war by public opinion. The latter argues that the pacification among Europe's liberal societies was dependent on their adventures in the colonies. Democratic wars with non-democracies thus become an intrinsic part of democratic peace, to be accounted for within the same framework. His account of how civilization and barbarism were co-constitutive identities adds historical and cultural depth to that observation, and 
thus advises against rationalist explanations of this duality of democratic peace and democratic war.

In terms of the behavior that defines the democratic peace as a historical phenomenon, one can again draw a distinction between Ish-Shalom and the other authors. With Ish-Shalom, "democratic peace" exists (in the world) foremost as a rhetorical commonplace. Political entrepeneurs speak (about) "democratic peace." Hobson adds to this an identification within "democratic peace" of a process of Othering, whereby nondemocracies become perceived as "ontologically and behaviorally threatening" to the maintenance of international peace and also suggests that a particular type of sociability was expected to mark the community of democracies; a certain closeness, the establishment of a "partnership". [Hippler $(2015,175]$ describes how at the Paris Peace Congress of 1849 the national flags hung "in fraternal bundles."] Joas and Knöbl add to this the observation - or at least the hypothesis - that a particular form of violence (bouts of violence, either for reasons of self-defense or for reasons of self-reinvigoration) form an inherent aspect of the practice of democratic peace. Ringmar explains how the liberal project feeds of moments of transgressive violence too. If the democratic peace, as a historical phenomenon, does not coincide with the liberal project, we should endeavor to specify how their violence differs. Are it the same "inclinations, personality, and passions," to quote Alexis de Tocqueville again, that motivated the destruction of Yuanmingyuan as those that motivated the Bush administration "to topple Sadam"? This is the kind of question that an account of the democratic peace as a historical phenomenon should seek to answer.

3. Does the idea that democratic peace is an historical phenomenon imply that it is a phenomenon of the past, that we are moving beyond the democratic peace? 
Our expectations about the longevity of the democratic peace as a historical finding depend very much on our explanatory accounts of the finding. If we follow the structural explanation of democratic peace, we will be the most optimistic, as also Ish-Shalom suggested, because democratic institutions appear to be firmly in place in most democracies. However, if we follow the normative explanation, the question becomes more challenging, as we will have to evaluate the strength and endurance of liberal values within democratic countries, which many observers are less optimistic about. Similarly, if we believe that the historical finding of a democratic peace was causally over-determined, maybe all we can do is wait and see. So many factors are in play, which can be combined into so many different configurations, that we simply cannot tell what will be the outcome.

With the democratic peace as a historical phenomenon, the matter is different. My provisional account of it in this essay includes little to make us believe that "democratic peace" will be abandoned as an international practice now that non-democratic countries appear to be rising to international prominence again. It might not be the most productive stance to cling to for democracies in our current historical situation, but if Joas' and Knöbl's assessment of the weaknesses of rationalism (as a theory of action, order, and change) are anything to go by, we should probably expect "democratic peace" to linger as both concept and practice. Maybe "democratic peace" will assume an increasingly incantatory aspect, but that is in no way against its nature. 


\section{Additional References}

Barbalet, Jack. 2012. Self-Interest and the Theory of Action. British Journal of Sociology 63 (3): 412-429.

Barkawi, Tarak. 2015a. Scientific Decay. International Studies Quarterly 59 (4): 827-829.

Barkawi, Tarak. 2015b. Red Herrings, Split Hairs, and Small Wars. ISQ Online Symposia. Available at http://www.isanet.org/Publications/ISO/Posts/ID/4851/Red-Herrings-Split-

Hairs-and-Small-Wars (Last accessed on 17 January 2016).

Barkawi, Tarak and Mark Laffey. 1999. The Imperial Peace: Democracy, Force and

Globalization. European Journal of International Relations 5 (4): 403-434.

Bueno de Mesquita, Bruce, James Morrow, Randolph Siverson, and Alastair Smith. 1999. An Institutional Explanation of the Democratic Peace. American Political Science Review 93 (4): 791-807.

Elman, Miriam Fendius. 1997. International History and the Democratic Peace. International History Review 19 (4): 866-885.

Hevia, James. 1995. Cherishing Men From Afar: Qing Guest Ritual and the Macartney Embassy of 1793. Durham: Duke University Press.

Hippler, Thomas. 2015. From Nationalist Peace to Democratic War: The Peace Congresses in Paris (1849) and Geneva (1867). 170-188 in Thomas Hippler and Milos Vec (eds.). Paradoxes of Peace in Nineteenth Century Europe. Oxford: Oxford University Press. 
Kratochwil, Friedrich. 2006. History, Action and Identity: Revisiting the 'Second Great

Debate' and Its Importance for Social Theory. European Journal of International Relations 12 (1): 5-29.

Maoz, Zeev and Bruce Russett. 1993. Normative and Structural Causes of the Democratic Peace, 1946-1986. American Political Science Review 87 (3): 624-638.

Owen IV, John. 2005. Iraq and the Democratic Peace. Foreign Affairs 84 (6): 122-127.

Poznansky, Michael. 2015a. Stasis or Decay? Reconciling Covert War and the Democratic Peace. International Studies Quarterly 59 (4): 815-826.

Poznansky, Michael. 2015b. Critical Statis: A Reply to Barkawi. ISQ Online Symposia. Available at http://www.isanet.org/Publications/ISQ/Posts/ID/4823/Critical-Stasis-A-Replyto-Barkawi (Last accessed on 17 January 2016).

Russett, Bruce. 1993. Grasping the Democratic Peace: Principles for a Post-Cold War World. Princeton: Princeton University Press.

Russett, Bruce. 2009. Democracy, War and Expansion Through Historical Lenses. European Journal of International Relations. 15 (1): 9-36.

Tarrow, Sidney. 2015. War, States, and Contention: A Comparative Historical Study. Ithaca and London: Cornell University Press.

Todorov, Tzvetan. 1984. The Conquest of America: The Question of the Other. New York: Harper and Collins.

Tuck, Richard. Hobbes. Oxford: Oxford University Press. 
Williams, Michael. 2001. The Discipline of Democratic Peace: Kant, Liberalism, and the Social Construction of Security Communities. European Journal of International Relations 7 (4):

525-553. 